\title{
A review of the management of phantom limb pain: challenges and solutions
}

\section{Cliff Richardson' \\ Jai Kulkarni²}

'University of Manchester, Division of Nursing Midwifery and Social Work, Manchester, UK, ${ }^{2}$ Specialized Ability Centre (Manchester), University Hospitals of South Manchester NHS Foundation Trust, Manchester, UK
Correspondence: Cliff Richardson University of Manchester, Division of Nursing, Midwifery and Social Work, Jean McFarlane Building, Oxford Road, Manchester, MI3 9PL, UK

Tel +440161 3067639

Fax +44 0161 3067707

Email Clifford.richardson@manchester. ac.uk
This article was published in the following Dove Press journal:

Journal of Pain Research

7 August 2017

Number of times this article has been viewed

Background: Phantom limb pain (PLP) occurs in 50\% and $80 \%$ of amputees. Although it is often classified as a neuropathic pain, few of the large-scale trials of treatments for neuropathic pain included sufficient numbers of PLP sufferers to have confidence that they are effective in this condition. Many therapies have been administered to amputees with PLP over the years; however, as of yet, there appears to be no first-line treatment.

Objectives: To comprehensively review the literature on treatment modalities for PLP and to identify the challenges currently faced by clinicians dealing with this pain.

Method: MEDLINE, EMBASE, CINAHL, British Nursing Index, Cochrane and psycINFO databases were searched using "Phantom limb" initially as a MeSH term to identify treatments that had been tried. Then, a secondary search combining phantom limb with each treatment was performed to find papers specific to each therapy. Each paper was assessed for its research strength using the GRADE system.

Results: Thirty-eight therapies were identified. Overall, the quality of evidence was low. There was one high-quality study which used repetitive transcutaneous magnetic stimulation and found a statistical reduction in pain at day 15 but no difference at day 30. Significant results from single studies of moderate level quality were available for gabapentin, ketamine and morphine; however, there was a risk of bias in these papers. Mirror therapy and associated techniques were assessed through two systematic reviews, which conclude that there is insufficient evidence to support their use.

Conclusion: No decisions can be made for the first-line management of PLP, as the level of evidence is too low. Robust studies on homogeneous populations, an understanding of what amputees consider a meaningful reduction in PLP and agreement of whether pain intensity is the legitimate therapeutic target are urgently required.

Keywords: phantom limb pain, review, treatment, pain

\section{Introduction}

Phantom limb pain (PLP) occurs in $50 \%-80 \%$ of limb amputees ${ }^{1-4}$ and is known to be highly fluctuant. ${ }^{1,5}$ As PLP is associated with deafferentation and is known to be associated with cortical reorganization ${ }^{6}$ of the somatosensory system, it is often classified as a neuropathic pain; however, no large neuropathic pain drug trials included sufficient number of people with PLP to have confidence that they are effective in this condition. ${ }^{7}$ This is reinforced by the updated Cochrane reviews for the use of amitriptyline, carbamazepine, gabapentin, pregabalin and lamotrigine in treating neuropathic pain. ${ }^{8-12}$ 
In 1980, Sherman identified that 43 treatments had been used to control $\mathrm{PLP}^{13}$ and since that time, multiple drugs, surgery and complementary therapies have been added to the list. According to a recent Cochrane review of pharmacologic interventions for PLP, there is inconclusive evidence for any single therapy. ${ }^{14}$

For a while, focus turned toward the potential to prevent rather than treat PLP by aggressively controlling preamputation or immediate postamputation pain. ${ }^{15-17}$ Results from these studies have been equivocal with the stronger studies favoring no effect. ${ }^{18}$ To add to the confusion, treatments used for acute PLP have often been commenced preemptively and it can be difficult to resolve these from studies on established PLP. More recently, treatments aimed at reversing cortical reorganizations, ${ }^{19}$ such as mirror therapy and associated treatments, have been the center of attention. ${ }^{20}$

This review has, therefore, explored the management of established PLP, with a remit to be as broad as possible to give practitioners all relevant data about how to treat this perplexing and intractable condition. It is hoped that by including all treatments rather than selecting them by method and quality, clinicians will be able to evaluate their treatment strategies against rumor and speculation. Additionally, our ambition is, through the appraisal of the literature, to identify the challenges that practitioners have when treating people with PLP and how best to resolve them.

\section{Method}

This should not be regarded as a systematic review; however, approaches consistent with systematic reviews have been utilized. In line with the Initiative on Methods, Measurement, and Pain Assessment in Clinical Trials (IMMPACT) criteria, the search was designed to identify treatments/therapies that improve one or more of the following outcomes: pain, function, global impression of change and lower side effects. ${ }^{18}$ MEDLINE, EMBASE, CINAHL, British Nursing Index, Cochrane and psycINFO were searched in April 2017 and as far back as their dates would allow using "Phantom limb" initially as a MeSH term to identify treatments that had been used previously. Then, a secondary search combining PLP with each treatment was undertaken to find papers specific to each therapy. The search strategy is outlined in Table 1.

\section{Inclusion/exclusion criteria}

Only human studies for established PLP were included. Studies treating PLP in the acute postoperative phase were excluded as it is very difficult to delineate PLP from stump pain (SP) in this period. All levels of evidence from single case studies to
Table I Search strategy

\begin{tabular}{ll}
\hline Step & Action \\
\hline I & "Phantom Limb" searched as MeSH term \\
2 & Titles searched for treatments \\
3 & List of treatments identified \\
4 & Second database search. "Phantom limb" combined with each \\
& treatment (included generic medication group and individual \\
& drugs from that group, i.e., "antidepressive agents" and \\
& "amitriptyline") \\
5 & Excluded non-English papers or if full text was unavailable \\
7 & Excluded all papers that were not treatment evaluations \\
& Reference lists of papers scanned for any papers not \\
& previously identified \\
\hline
\end{tabular}

Table 2 Example of search on MEDLINE for antidepressive agents

\begin{tabular}{|c|c|c|c|}
\hline MeSH term & Hits & $\begin{array}{l}\text { Boolean } \\
\text { operator "And" }\end{array}$ & $\begin{array}{l}\text { Inclusion/ } \\
\text { exclusion applied }\end{array}$ \\
\hline Phantom limb & 1725 & 8 & 2 \\
\hline Amitriptyline & 6412 & & \\
\hline Phantom limb & 1725 & 2 & 2 \\
\hline Doxepin & 758 & & \\
\hline Phantom limb & 1725 & 0 & 0 \\
\hline Nortriptyline & 2133 & & \\
\hline Phantom limb & 1725 & 14 & 1 \\
\hline \multirow{2}{*}{$\begin{array}{l}\text { Antidepressive } \\
\text { agents }\end{array}$} & 39,073 & & \\
\hline & & & Total $=5$ \\
\hline
\end{tabular}

randomized controlled trials (RCTs) were included. A modified PRISMA flow diagram for antidepressive agents as an example for the process for each treatment is shown in Table 2 .

\section{Quality assessment}

The GRADE system was utilized ${ }^{21}$ to assess the quality of each paper. GRADE has been said to overcome some of the arbitrariness of other categorization systems which weigh particular research methods, even when there may be significant biases present in individual studies using those methods. GRADE utilizes four levels of quality, High, Moderate, Low and Very Low, and takes account of limitations, inconsistencies, directness and imprecision of the study for the topic being investigated. The quality assessment criteria used are included in Table 3. One of the main issues encountered within the quality assessment process was the fact that many papers that would normally have been assessed as being high quality used mixed samples, that is, upper (major or minor) and lower limb (major or minor) amputees, or included pain reduction of PLP and SP within the outcomes. If it was not possible to extract the PLP patients from the pooled data, the quality assessment was downgraded accordingly. All 
Table 3 Evidence is assessed using four levels of quality as defined by the GRADE system

\begin{tabular}{|c|c|c|}
\hline GRADE score & Description & Agreed criteria within studies used for this comprehensive review \\
\hline High quality & $\begin{array}{l}\text { Further research is very unlikely } \\
\text { to change our confidence in the } \\
\text { estimate of effect }\end{array}$ & $\begin{array}{l}\text { Randomization } \\
\text { Control group } \\
\text { Active placebo } \\
\text { Homogenous sample of amputees } \\
\text { PLP sole outcome or able to be clearly differentiated from other outcomes, for example, SP } \\
\text { Sample size decided by power calculation or at least } 50 \text { ( } 25 \text { in cross-over studies) to enable } \\
\text { comparative statistics to be performed }\end{array}$ \\
\hline $\begin{array}{l}\text { Moderate } \\
\text { quality }\end{array}$ & $\begin{array}{l}\text { Further research is likely to have } \\
\text { an important impact on our } \\
\text { confidence in the estimate of the } \\
\text { effect and may change the estimate }\end{array}$ & $\begin{array}{l}\text { Randomization } \\
\text { Control group } \\
\text { Inactive placebo } \\
\text { Heterogeneous sample of amputees } \\
\text { PLP sole outcome or able to be clearly differentiated from other outcomes, for example, SP } \\
\text { Sample size not powered }\end{array}$ \\
\hline Low quality & $\begin{array}{l}\text { Further research is very likely to } \\
\text { have an important impact on our } \\
\text { confidence in the estimate of effect } \\
\text { and is likely to change the estimate }\end{array}$ & $\begin{array}{l}\text { Prospective study/randomized study with no control group or very small sample size } \\
\text { Heterogeneous sample of amputees } \\
\text { PLP not sole outcome or unable to differentiate from other outcomes } \\
\text { Small sample size or small number of sample with PLP }\end{array}$ \\
\hline $\begin{array}{l}\text { Very low } \\
\text { quality }\end{array}$ & $\begin{array}{l}\text { Any estimate of effect is very } \\
\text { uncertain }\end{array}$ & $\begin{array}{l}\text { Case study } \\
\text { Very low number case series }\end{array}$ \\
\hline
\end{tabular}

Source: Data from Guyatt et al. ${ }^{21}$

Abbreviations: PLP, phantom limb pain; SP, stump pain.

potential risks of bias were determined to impact on the confidence in the estimate of the effect from that study, and the more the risks, the lower the GRADE classification.

\section{Data extraction and synthesis}

All papers were reviewed by the first author and any doubts resolved by discussion with the second author. Each treatment was isolated and considered individually. Due to the general low quality of the studies, it was only possible to analyze the data narratively.

\section{Results}

Various systematic reviews were identified and used to confirm the appraisals of individual treatments, except for two robust and recent reviews of mirror therapy and associated treatments. Due to the complexity and number of different mirror therapy and associated techniques that have been tested, only the systematic review results are reported.

Eighty-six papers were appraised. One study plus the two systematic reviews were assessed to be of high quality, nine were assessed as moderate quality (Table 4) and 75 as low or very low quality (Table 5). Pharmacologic, surgical and nonpharmacologic treatments have been used to treat PLP.

\section{High-quality evidence}

A systematic review of 20 mirror therapy studies and another of 15 studies of movement representation techniques (often utilized alongside mirror therapy) to control PLP have found insufficient evidence to support their use for PLP. ${ }^{20,22}$

One high-quality double-blind, placebo-controlled trial $(\mathrm{n}=54)$ using repetitive transcranial magnetic stimulation to stimulate the primary motor cortex of traumatic amputees (land mine victims) found a significant reduction in pain visual analog scale (VAS) at 15 days $(p=0.03$ ); however, there was no longer a statistical difference at 30 days. ${ }^{23}$

\section{Moderate-quality evidence}

One $\mathrm{RCT}^{24}$ which used pain intensity as the primary outcome $(n=39)$ found no difference between amitriptyline and the active placebo benztropine. Function was measured as a secondary outcome and this too showed a nonsignificant difference, while satisfaction with life was higher $(p=0.04)$ in the placebo group. Fifteen side effects were reported, with dry mouth being the most severe in the amitriptyline group.

Two randomized, double-blind, cross-over studies comparing gabapentin with placebo ${ }^{25,26}$ were found. Methodologically, both were well constructed; but as they used inactive placebo and had low sample sizes, 19 (complete data on 14) and 24, respectively, they were judged to be of moderate quality. Bone et al found that gabapentin statistically reduced pain intensity at 6 weeks. The average VAS reduced from 6.6 (SD 1.8) to 2.9 (SD 2.2) in the gabapentin group, as compared to a reduction from 6.7 (SD 1.9) to 5.1 (SD 2.2) in the placebo group. No statistical difference 
Table 4 Details of papers assessed to be of moderate quality with reasons for potential bias identified

\begin{tabular}{|c|c|c|c|c|}
\hline Reference & Methods & Participants & Outcomes & Risk of bias \\
\hline Bone et $\mathrm{al}^{25}$ & $\begin{array}{l}\text { Gabapentin } \\
\text { RCT, double-blind, cross- } \\
\text { over, inactive placebo } \\
\text { Population PLP }>4 / 10 \text { for } \\
6 \text { months }\end{array}$ & $\begin{array}{l}33 \text { referred } \\
19 \text { recruited ( } 16 \text { males) } \\
14 \text { completed } \\
15 \text { lower limb amputees }\end{array}$ & $\begin{array}{l}\text { PLP VAS difference from baseline ( } p=0.025 \\
\text { at } 6 \text { weeks point, otherwise ns) } \\
\text { HAD (ns) } \\
\text { Bartel index (function), ns } \\
\text { Sleep interference (ns) }\end{array}$ & $\begin{array}{l}\text { Small sample size } \\
\text { Inactive placebo } \\
\text { Multiple tests performed VAS } \\
6 \text { weeks result may be artifact }\end{array}$ \\
\hline $\begin{array}{l}\text { Maier } \\
\text { et } \mathrm{al}^{31}\end{array}$ & $\begin{array}{l}\text { Memantine } \\
\text { Double-blind, placebo- } \\
\text { controlled RCT } \\
\text { PLP for at least I year }(>4 / 10) \\
4 \text { weeks follow-up }\end{array}$ & $\begin{array}{l}36 \text { participants } \\
\text { Mixed upper/lower limb } \\
\text { Mixed major/minor } \\
\text { amputation }\end{array}$ & PLP VAS (ns) & $\begin{array}{l}\text { Mixed group } \\
\text { Short follow-up } \\
\text { Small sample size } \\
\text { Unclear how PLP and SP are } \\
\text { differentiated }\end{array}$ \\
\hline $\begin{array}{l}\text { Nikolajsen } \\
\text { et } \mathrm{al}^{29}\end{array}$ & $\begin{array}{l}\text { Memantine } \\
\text { Double-blind, cross-over RCT } \\
\text { PLP or neuropathic pain } \\
\text { postamputation }>3 / 10\end{array}$ & $\begin{array}{l}19 \text { participants ( } 14 \text { males) } \\
4 \text { nerve injury } \\
7 \text { finger amputations } \\
\text { I upper limb amputation } \\
7 \text { lower limb amputations }\end{array}$ & $\begin{array}{l}\text { Daily mean VAS (ns) } \\
\text { MPQ (ns) } \\
\text { Evoked pain (ns) }\end{array}$ & $\begin{array}{l}\text { Mixed group of conditions/ } \\
\text { amputations } \\
\text { Small sample size } \\
\text { Worst pain used, so unclear } \\
\text { effect on PLP }\end{array}$ \\
\hline $\begin{array}{l}\text { Nikolajsen } \\
\text { et } \mathrm{al}^{28}\end{array}$ & $\begin{array}{l}\text { Ketamine } \\
\text { Double-blind, cross-over } \\
\text { RCT, inactive placebo }\end{array}$ & $\begin{array}{l}\text { II participants (8 males) } \\
\text { PLP or SP } \\
3 \text { finger amputations } \\
2 \text { upper limb } \\
6 \text { lower limb } \\
7 \text { cancer } \\
\text { I trauma } \\
3 \text { surgical }\end{array}$ & $\begin{array}{l}\text { VAS }(p<0.05) \\
\text { MPQ }(p<0.05) \\
\text { Evoked pain ( } p<0.05 \text { for some areas only) }\end{array}$ & $\begin{array}{l}\text { Mixed PLP and SP } \\
\text { Mixed amputation/level } \\
\text { Small sample size } \\
\text { Short duration of effect } \\
\text { Side effects of ketamine }\end{array}$ \\
\hline $\begin{array}{l}\text { Robinson } \\
\text { et } \mathrm{al}^{24}\end{array}$ & $\begin{array}{l}\text { Amitriptyline } \\
\text { RCT, active placebo } \\
\text { (benztropine) } \\
\text { Amputation-related pain for } \\
\text { at least } 6 \text { months }\end{array}$ & $\begin{array}{l}39 \text { participants } \\
\text { Mixed upper/lower limb } \\
7 \text { PLP, } 6 \text { SP, } 24 \text { both, } \\
2 \text { other pain }\end{array}$ & $\begin{array}{l}\text { Average VAS (ns) } \\
\text { MPQ (ns) } \\
\text { BPI (ns) } \\
\text { Function (FIM), ns } \\
\text { Satisfaction with life (ns) } \\
\text { Handicap (CHART), ns }\end{array}$ & $\begin{array}{l}\text { Mixed amputation } \\
\text { Mixed PLP and SP } \\
\text { Small sample size }\end{array}$ \\
\hline $\begin{array}{l}\text { Smith } \\
\text { et } \mathrm{al}^{26}\end{array}$ & $\begin{array}{l}\text { Gabapentin } \\
\text { Double-blind, cross-over } \\
\text { RCT, inactive placebo }\end{array}$ & $\begin{array}{l}24 \text { participants } \\
\text { Lower limb amputation } \\
\text { PLP or SP (VAS }>3 \text { in the } \\
\text { last month) }\end{array}$ & $\begin{array}{l}\text { Composite NRS }(0-10), \text { ns } \\
\text { Global benefit score }(p<0.05) \\
\text { BPI (ns) } \\
\text { MPQ (ns) } \\
\text { Depression (CES-D), ns } \\
\text { Function (FIM), ns } \\
\text { Satisfaction with life (ns) } \\
\text { Handicap (CHART) }\end{array}$ & $\begin{array}{l}\text { Mixed pain PLP/SP } \\
\text { Small sample size } \\
\text { Inactive placebo }\end{array}$ \\
\hline $\begin{array}{l}\text { Wiech } \\
\text { et } \mathrm{al}^{30}\end{array}$ & $\begin{array}{l}\text { Memantine } \\
\text { Double-blind, cross-over } \\
\text { RCT, inactive placebo }\end{array}$ & $\begin{array}{l}8 \text { participants } \\
\text { Upper limb } \\
4 \text { above elbow } \\
3 \text { shoulder } \\
\text { I hand } \\
\text { PLP only }\end{array}$ & $\begin{array}{l}\text { Mean VAS during treatment (ns) } \\
\text { MEG scan (cortical reorganization), ns }\end{array}$ & $\begin{array}{l}\text { Small sample size } \\
\text { Inactive placebo } \\
\text { Mixed upper limb sample }\end{array}$ \\
\hline $\mathrm{Wu}$ et $\mathrm{al}^{32}$ & $\begin{array}{l}\text { Lidocaine and morphine } \\
\text { Double-blind, cross-over } \\
\text { RCT, active placebo } \\
\text { (diphenhydramine) }\end{array}$ & $\begin{array}{l}\text { 3I participants } \\
\text { PLP or SP or both } \\
\text { Upper/lower limb } \\
\text { amputees }(9 / 22)\end{array}$ & $\begin{array}{l}\text { Pain VAS (lidocaine SP }-p<0.01 \text { ) (morphine } \\
\text { SP }-p<0.01 \text { and } P L P-p<0.00 I \text { ) } \\
\text { Sedation VAS pain relief score }(\%) \\
\text { NNT (lidocaine }- \text { SP } 2.5 \text { for } 30 \% \text { reduction) } \\
\text { (morphine }- \text { SP } 2.1 \text { for } 30 \% \text { reduction and } \\
1.9 \text { for } 30 \% \text { reduction in PLP) }\end{array}$ & $\begin{array}{l}\text { Mixed sample of amputees } \\
\text { PLP and SP } \\
\text { Small sample size for multiple } \\
\text { calculations } \\
\text { Short follow-up ( } 80 \text { minutes) }\end{array}$ \\
\hline$W u$ et $\mathrm{al}^{33}$ & $\begin{array}{l}\text { Mexiletine and morphine } \\
\text { Double-blind, cross-over } \\
\text { RCT, inactive placebo }\end{array}$ & $\begin{array}{l}60 \text { enrolled, } 45 \text { two drug } \\
\text { periods, } 35 \text { all three } \\
\text { phases }\end{array}$ & $\begin{array}{l}\text { Pain VAS change from baseline } \\
\text { Morphine pain relief vs placebo } p=0.0003 \\
\text { and vs mexiletine } p=0.0003 \\
\text { Morphine NNT for } 33 \% \text { pain reduction }=4.5 \\
\text { Side effects high in morphine group }\end{array}$ & $\begin{array}{l}\text { Mixed sample of amputees } \\
\text { PLP and SP } \\
\text { Large dropout } \\
\text { Inactive placebo }\end{array}$ \\
\hline
\end{tabular}

Abbreviations: BPI, brief pain inventory; CES-D, Center for Epidemiologic Studies Depression Scale; CHART, Craig Handicap Assessment and Reporting Technique; FIM, Functional Independence Measure; HAD, hospital anxiety and depression scale; MEG, Magnetoencephalography; MPQ, McGill pain questionnaire; NNT, number needed to treat; NRS, numerical rating scale; ns, no statistical difference; PLA, phantom limb awareness; PLP, phantom limb pain; PLS, phantom limb sensation; RCT, randomized controlled trial; SP, stump pain; VAS, visual analog scale. 
Table 5 Low- and very low-quality studies

\begin{tabular}{|c|c|c|c|c|}
\hline $\begin{array}{l}\text { Treatment } \\
\text { type }\end{array}$ & $\begin{array}{l}\text { Specific } \\
\text { treatment }\end{array}$ & Number of studies & Outcomes & Comments \\
\hline $\begin{array}{l}\text { Antidepressants } \\
\text { (tricyclic) }\end{array}$ & $\begin{array}{l}\text { Amitriptyline } \\
\text { Doxepin }\end{array}$ & $\begin{array}{l}\text { Two case studies } \\
\text { One case series }(n=5)\end{array}$ & Reduction in pain intensity & $\begin{array}{l}\text { Side effects } \\
\text { Case series combined medication }\end{array}$ \\
\hline Anticonvulsants & $\begin{array}{l}\text { Gabapentin } \\
\text { Pregabalin } \\
\text { Topiramate } \\
\text { Carbemazepam } \\
\text { Clonazepam }\end{array}$ & $\begin{array}{l}\text { One case series }(n=7) \\
\text { Five case studies }\end{array}$ & Reduction in pain intensity & Small sample sizes \\
\hline Calcitonin & Calcitonin & $\begin{array}{l}\text { One review } \\
\text { One case series }(n=10) \\
\text { One double-blind, cross-over trial }(n=10)\end{array}$ & $\begin{array}{l}\text { Reduction in pain intensity } \\
\text { No reduction in pain intensity }\end{array}$ & $\begin{array}{l}\text { Review focused mainly on acute } \\
\text { PLP } \\
\text { Side effects in all studies }\end{array}$ \\
\hline \multirow[t]{2}{*}{ antagonists } & Ketamine & $\begin{array}{l}\text { One double-blind, cross-over trial }(n=10) \\
\text { One case series }(n=3) \\
\text { One case study } \\
\text { One case study }\end{array}$ & $\begin{array}{l}\text { Reduction in pain intensity } \\
\text { Pain exacerbated }\end{array}$ & $\begin{array}{l}\text { Side effects in all studies } \\
\text { Dextromethorphan and } \\
\text { methadone have mixed analgesic } \\
\text { effect }\end{array}$ \\
\hline & $\begin{array}{l}\text { Memantine } \\
\text { Dextromethorphan } \\
\text { Methadone }\end{array}$ & $\begin{array}{l}\text { One case series }(n=2) \\
\text { One case series }(n=3) \\
\text { One case series }(n=4)\end{array}$ & $\begin{array}{l}\text { Reduction in pain intensity } \\
\text { Reduction in pain intensity } \\
\text { Reduction in pain intensity }\end{array}$ & \\
\hline anesthetics & $\begin{array}{l}\text { Lidocaine } \\
\text { Mexiletine } \\
\text { Ropivacaine }\end{array}$ & $\begin{array}{l}\text { One randomized study }(n=14) \\
\text { One case series }(n=3) \\
\text { One case series }(n=8)\end{array}$ & $\begin{array}{l}\text { No reduction in pain intensity } \\
\text { In } 2 / 3 \text {, pain intensity reduced } \\
\text { In } 6 / 8 \text {, pain reduction } \\
\text { achieved }\end{array}$ & $\begin{array}{l}\text { Compared with botox } \\
\text { Small sample size } \\
\text { Peripheral nerve block }\end{array}$ \\
\hline Opioids & $\begin{array}{l}\text { Bupivacaine } \\
\text { Morphine } \\
\text { Fentanyl }\end{array}$ & $\begin{array}{l}\text { One case study } \\
\text { One case study }(n=12) \\
\text { Three case studies }\end{array}$ & $\begin{array}{l}\text { Pain intensity reduced } \\
\text { Reduction in pain intensity }\end{array}$ & $\begin{array}{l}\text { Contralateral myofascial injection } \\
\text { Small sample sizes }\end{array}$ \\
\hline Beta-blockers & Propranolol & Three case studies & Reduction in pain intensity & Dated \\
\hline $\begin{array}{l}\text { Serotonin } \\
\text { reuptake } \\
\text { inhibitors }\end{array}$ & $\begin{array}{l}\text { Fluoxetine } \\
\text { Duloxetine } \\
\text { Milnacipran }\end{array}$ & Three case studies & Reduction in pain intensity & Small sample sizes \\
\hline \multirow[t]{2}{*}{ Surgery } & DREZ & Two case series & & $\begin{array}{l}\text { Unable to determine PLP effect } \\
\text { due to mixed group }\end{array}$ \\
\hline & & $\begin{array}{l}\text { Two case series } \\
\text { One case study }\end{array}$ & $\begin{array}{l}36 \% \text { and } 64 \% \text { achieved pain } \\
\text { reduction, respectively } \\
\text { Reduction in pain intensity }\end{array}$ & $\begin{array}{l}\text { Mixed samples and small numbers } \\
\text { with PLP } \\
\text { Single case }\end{array}$ \\
\hline Acupuncture & $\begin{array}{l}\text { Acupuncture } \\
\text { Electroacupuncture }\end{array}$ & $\begin{array}{l}\text { Three case studies } \\
\text { One case series }(n=9)\end{array}$ & $\begin{array}{l}\text { Reduction in pain intensity } \\
\text { In } 5 / 9,50 \% \text { reduction in pain } \\
\text { intensity }\end{array}$ & $\begin{array}{l}\text { Small sample sizes } \\
\text { Small sample size }\end{array}$ \\
\hline Farabloc & Farabloc & $\begin{array}{l}\text { One double-blind, cross-over study } \\
(n=52)\end{array}$ & Reduction in pain intensity & Large dropout high risk of bias \\
\hline \multirow[t]{2}{*}{ Feedback } & Biofeedback & $\begin{array}{l}\text { Two case series }(n=16 ; n=9) \\
\text { Two case studies }\end{array}$ & Reduction in pain intensity & Small sample sizes \\
\hline & $\begin{array}{l}\text { Sensory } \\
\text { discrimination }\end{array}$ & One controlled comparative study $(n=10)$ & Reduction in pain intensity & $\begin{array}{l}\text { Inactive placebo } \\
\text { Low sample size }\end{array}$ \\
\hline Hypnosis & Hypnosis & Two case series $(n=25 ; n=20)$ & Reduction in pain intensity & Mixed group PLP/stump pain \\
\hline Reflexology & Reflexology & One case series $(n=10)$ & Reduction in pain intensity & Small sample size \\
\hline \multirow[t]{5}{*}{$\begin{array}{l}\text { Stimulation } \\
\text { therapies }\end{array}$} & TENS & $\begin{array}{l}\text { Two trials } \\
\text { Seven case series or case studies }\end{array}$ & Reduction in pain intensity & $\begin{array}{l}\text { Dated } \\
\text { Small sample size } \\
\text { Small numbers }\end{array}$ \\
\hline & SCS & Five case series & Reduction in pain intensity & $\begin{array}{l}\text { Lack of specificity and small sample } \\
\text { sizes }\end{array}$ \\
\hline & $\begin{array}{l}\text { Motor cortex } \\
\text { stimulation }\end{array}$ & Six case series & Variable results & $\begin{array}{l}\text { In largest sample }(n=5) \text {, only one } \\
\text { achieved a reduction in pain }\end{array}$ \\
\hline & DBS & Two case series & Variable results & Small sample sizes \\
\hline & ECT & $\begin{array}{l}\text { One case series }(n=2) \\
\text { One case study }\end{array}$ & Reduction in pain intensity & Small sample sizes \\
\hline $\begin{array}{l}\text { Therapeutic } \\
\text { touch }\end{array}$ & Therapeutic touch & Two case series & Reduction in pain intensity & Total number $n=6$ \\
\hline
\end{tabular}

Abbreviations: DBS, deep brain stimulation; DREZ, Dorsal-Root Entry Zone; ECT, electroconvulsive therapy; NMDA, N-methyl-D-aspartate; PLP, phantom limb pain; SCS, spinal cord stimulation; TENS, transcutaneous electrical nerve stimulation. 
was found for function. Smith et al measured all four of the important IMMPACT outcomes. No statistical difference in pain intensity was found between the gabapentin group and the placebo group, but participants experienced a statistically significant difference in their pain global improvement scale. The difference from baseline VAS for worst PLP was 1.15 (SD 2.41) in the gabapentin group and 0.58 (SD 2.86) in the placebo group, but the participants considered this to be a meaningful reduction. Changes in function scores were not significantly altered and a larger percentage of participants believed that the benefits of gabapentin outweighed the side effects (54.2\% vs $16.8 \%$ ). A recent systematic review ${ }^{27}$ confirmed our appraisal and identified one additional study by Nikolajsen et al which was excluded here as it used gabapentin pre-emptively and immediately postamputation.

A randomized, double-blind, cross-over study of moderate quality due to short duration of effect measurement (80 minutes), low sample size ( $n=11)$, mixed group of amputees and mixed PLP/SP found that ketamine reduced average PLP intensity to $<10 \%$ of the average baseline VAS value. ${ }^{28}$ Nine of the 11 participants experienced side effects during ketamine infusion.

Memantine has three moderate-quality (small and mixed samples using inactive placebo) randomized, double-blind, placebo-controlled studies, all of which found no statistical difference in pain $\mathrm{VAS} .{ }^{29-31}$

There is one moderate-quality (mixed group of amputees with PLP or SP or both) randomized, double-blind, crossover study which compared lidocaine with morphine and an active placebo (diphenhydramine) on 31 amputees. No statistically significant reduction in PLP intensity was found for lidocaine during and up to 30 minutes after the completion of an intravenous infusion. ${ }^{32}$ In the same study, morphine significantly reduced pain intensity with a number needed to treat for PLP of 1.9, but as pain VAS was only measured for 30 minutes after the end of an intravenous infusion, this can only be judged as effective for this short period of time.

A follow-up moderate-quality RCT (inactive placebo, high dropout and mixed sample) comparing morphine, mexiletine (the oral derivative of lidocaine) and placebo found that morphine reduced pain by $53 \%(p=0.0003)$. No statistical difference was found for mexiletine. ${ }^{33}$

\section{Low-/very low-quality evidence}

\section{Pharmacologic treatments}

The following pharmacologic treatments have been tried for PLP: amitriptyline, ${ }^{34,35}$ doxepin, ${ }^{35-37}$ gabapentin, ${ }^{38}$ pregabalin, ${ }^{39}$ topiramate, ${ }^{40}$ carbemazepam, ${ }^{41,42}$ clonazepam, ${ }^{43}$ calcitonin, ${ }^{44-46}$ ketamine,${ }^{46-49}$ memantine, ${ }^{50}$ dextromethorphan, ${ }^{51}$ methadone, ${ }^{52}$ lidocaine, ${ }^{53}$ mexiletine, ${ }^{54}$ ropivicaine, ${ }^{55}$ bupivacaine,${ }^{56,57}$ morphine, ${ }^{35,58,59}$ fentanyl, ${ }^{60}$ propranolol, ${ }^{61-63}$ fluoxetine, ${ }^{64}$ duloxetine ${ }^{39}$ and milnacipran. ${ }^{65}$ The vast majority found that PLP intensity was reduced, but the low methodological quality and small sample sizes mean that no clinical decisions should be made based on these studies.

\section{Surgical treatments}

Various authors have reported that neurectomy, rhizotomy, sympathectomy, cordotomy and myelotomy have all been attempted as treatments for PLP, ${ }^{6-69}$ but no papers were found for any of these surgical treatments. The only surgery used to treat PLP identified by this search is Dorsal-Root Entry Zone lesioning. ${ }^{70-74}$ Lack of specificity and low sample size make it impossible to make any conclusions about the effect of Dorsal-Root Entry Zone on established PLP.

\section{Nonpharmacologic treatments}

The following nonpharmacologic treatments have been tested on PLP: acupuncture/electroacupuncture, ${ }^{75-79}$ biofeedback and other feedback mechanisms, ${ }^{80-84}$ Farabloc,${ }^{85}$ hypnosis, ${ }^{86-91}$ reflexology, ${ }^{92}$ transcutaneous electrical nerve stimulation, ${ }^{93-101}$ spinal cord stimulation, ${ }^{102-107}$ motor cortex stimulation, ${ }^{107-112}$ deep brain stimulation, ${ }^{13,114}$ electroconvulsive therapy, ${ }^{115,116}$ transcranial magnetic stimulation ${ }^{117-119}$ and therapeutic touch. ${ }^{120,121}$ Once again, the majority found a reduction in pain VAS; however, these are small case studies or case series, hence no clinical judgments should be made based on these results.

\section{Discussion - the challenges for future research}

If mirror therapy and associated techniques are considered as a single therapy, then 38 different treatments/therapies have been reviewed. The quality of the majority of PLP treatment studies is low, with only three papers appraised to be high quality: two systematic reviews of mirror therapy and associated techniques plus one study on repetitive transcranial magnetic stimulation. All three have produced equivocal findings and do not help clinicians to decide treatment regimens; but from the nine moderate-quality papers, there is tentative support for the use of gabapentin, ketamine and morphine. This tentatively agrees with the recommendations from a recent consensus conference on neurorehabilitation which included the treatment of PLP. ${ }^{122}$ The consensus included 
other treatments found to have efficacy in the other conditions that the conference discussed and, hence, has a lower specificity than our current review.

One factor that limits the ability to judge the research performed so far is that a meaningful pain reduction for PLP is not known. Smith et al's study on gabapentin is the only one that measured meaningful pain relief. In this case, the participants stated that an average VAS reduction of $1.15 \mathrm{~cm}$ was meaningful even when compared to the average reduction of $0.58 \mathrm{~cm}$ achieved by the inactive placebo. This relatively small change was not statistically significant, but was clinically significant to the participants. It is likely that all pain conditions will have different values for a meaningful level of pain reduction and it is possible that the higher the baseline VAS, the greater the reduction that has to be achieved. ${ }^{123}$ In complex regional pain syndrome, one study found that a relative $50 \%$ or absolute $3 \mathrm{~cm}$ reduction is clinically meaningful. ${ }^{124}$ Future studies need to ensure that a global impression of change in pain is utilized to allow an assessment of what practitioners need to achieve from any therapy. Unfortunately, this does not help in the decision making for the treatment of PLP because if a reduction of $<1 \mathrm{~cm}$ on VAS is sufficient, then it becomes possible that most of the therapies utilized previously, which reduced pain intensity, should be re-evaluated in more robust trials.

Furthermore, the fluctuant nature of PLP has not been factored into studies so far. It has been identified that commonly, amputees with PLP have 1-10 episodes a day and the most common duration for an episode is $1-10$ minutes. ${ }^{1,5}$ However, these groups do not necessarily overlap; so, someone having 10 episodes a day with each episode being 1 hour in duration is experiencing pain for 10 hours a day. Conversely, someone experiencing one episode lasting for 10 hours is similarly affected. This means that potentially some amputees with PLP would prefer the primary outcome to be to reduce the number or the length of the PLP episodes rather than reduce the intensity. The challenge for researchers is to build this into the methods of future studies.

The use of mirror therapy and associated techniques (including imagery, virtual reality and immersive therapies) has expanded in recent years. Current evidence though is difficult to judge, as there does not appear to be a defined standard for what constitutes mirror therapy and various mechanisms have been proposed for the effects of mirror therapy, including reversal of cortical reorganizations, relinking the visual and motor systems, activating mirror neurons in the contralateral brain, modulation of pain pathways, the reawakening of proprioceptive memories and the reversal of a potential neglect syndrome. ${ }^{125-128}$ Future mirror therapy research needs to be refined to assist elucidation between these potential mechanisms. Currently, comparison between studies is almost impossible; so, forthcoming studies need to control for the individual elements within mirror therapy to assess which are the most important and if they are additive. Brodie et al performed the largest trial of mirror therapies; however, there are substantial weaknesses to the study. ${ }^{129}$ Although 80 amputees were recruited, only 15 had PLP at the time of the mirror intervention. No estimate of the ongoing effects was measured to see if the participants experienced fewer episodes or less-intense episodes after the therapy. The conclusion that mirror therapy did not affect PLP, therefore, has a high risk of bias. In addition, two newer studies were not captured by the systematic reviews utilized by our review to assess the efficacy of mirror therapy and associated techniques. ${ }^{130,131}$ Brunelli et al reported significant reduction in PLP intensity $(n=51)$. However, it is impossible to identify which participants had PLP and which phantom limb sensation, as both were inclusion criteria; hence, potential bias remains high. Yildirim and Kanan recruited a very small sample of 15 amputees using a quasi-experimental approach and found a significant reduction in PLP intensity. Currently, therefore, these do not influence the conclusions from the previous reviews.

Experience suggests that amputees have difficulty differentiating between PLP and SP and other phantom phenomena such as exteroceptive sensation. ${ }^{1}$ So, doubt is attributed to studies that do not convincingly resolve between these phenomena. Future studies need to be designed appropriately in order to move knowledge forward. Methodological issues considered to be important are: heterogeneity of samples, that is, upper and lower limb amputees, major and minor amputation, acute vs chronic PLP, traumatic vs surgical amputation and cancer vs noncancer related amputation; active placebos are required for controlled trials; and follow-up time needs to be adequate. It is essential that all studies evaluating treatment for PLP use IMMPACT outcomes. Larger and better controlled studies are required and encouraged before an informed decision can be made about all therapies used to treat PLP. At present, though, there is not enough evidence to decide what would be the most appropriate treatment for people experiencing established PLP.

\section{Disclosure}

The authors report no conflicts of interest in this work. 


\section{References}

1. Richardson C, Glenn S, Nurmikko T, Horgan M. Incidence of phantom phenomena including phantom limb pain 6 months after major lower limb amputation in patients with peripheral vascular disease. Clin $J$ Pain. 2006;22(4):353-358.

2. Kooijman CM, Dijkstra PU, Geertzen JH, Elzinga A, van der Schans CP. Phantom pain and phantom sensations in upper limb amputees: an epidemiological study. Pain. 2000;87(1):33-41.

3. Ehde DM, Czerniecki JM, Smith DG, et al. Chronic phantom sensations, phantom pain, residual limb pain, and other regional pain after lower limb amputation. Arch Phys Med Rehabi. 2000;81(8):1039-1044.

4. Dijkstra PU, Geertzen JH, Stewart R, van der Schans CP. Phantom pain and risk factors: a multivariate analysis. J Pain Symptom Manage. 2002;24(6):578-585.

5. Richardson C, Crawford K, Milnes K, Bouch E, Kulkarni J. A clinical evaluation of postamputation phenomena including phantom limb pain after lower limb amputation in dysvascular patients. Pain Manag Nurs. 2015;16(4):561-569.

6. Flor H. Remapping somatosensory cortex after injury. Adv Neurol. 2003;93:195-204.

7. Finnerup NB, Sindrup SH, Jensen TS. The evidence for pharmacological treatment of neuropathic pain. Pain. 2010;150(3):573-581.

8. Moore RA, Derry S, Aldington D, Cole P, Wiffen PJ. Amitriptyline for neuropathic pain in adults. Cochrane Database Syst Rev. 2015;(7):CD008242.

9. Wiffen PJ, Derry S, Moore RA, Kalso EA. Carbamazepine for chronic neuropathic pain and fibromyalgia in adults. Cochrane Database Syst Rev. 2014;(4):CD005451.

10. Moore RA, Wiffen PJ, Derry S, Toelle T, Rice AS. Gabapentin for chronic neuropathic pain and fibromyalgia in adults. Cochrane Database Syst Rev. 2014;(4):CD007938.

11. Wiffen PJ, Derry S, Moore RA, et al. Antiepileptic drugs for neuropathic pain and fibromyalgia - an overview of Cochrane reviews. Cochrane Database Syst Rev. 2013;(11):CD010567.

12. Wiffen PJ, Derry S, Moore RA. Lamotrigine for chronic neuropathic pain and fibromyalgia in adults. Cochrane Database Syst Rev. 2013;(12):CD006044

13. Sherman RA. Published treatments of phantom limb pain. Am J Phys Med. 1980;59(5):232-244.

14. Alviar MJ, Hale T, Dungca M. Pharmacologic interventions for treating phantom limb pain. Cochrane Database Syst Rev. 2016;10: CD006380.

15. Jahangiri M, Jayatunga AP, Bradley JW, Dark CH. Prevention of phantom pain after major lower limb amputation by epidural infusion of diamorphine, clonidine and bupivacaine. Ann R Coll Surg Engl. 1994;76(5):324-326.

16. Nikolajsen L, Ilkjaer S, Christensen JH, Kroner K, Jensen TS. Randomised trial of epidural bupivacaine and morphine in prevention of stump and phantom pain in lower-limb amputation. Lancet. 1997;350(9088):1353-1357.

17. Nikolajsen L, Finnerup NB, Kramp S, Vimtrup AS, Keller J, Jensen TS. A randomized study of the effects of gabapentin on postamputation pain. Anesthesiology. 2006;105(5):1008-1015.

18. Richardson C. Nursing aspects of phantom limb pain following amputation. Br J Nurs. 2008;17(7):422-426.

19. Flor H. Maladaptive plasticity, memory for pain and phantom limb pain: review and suggestions for new therapies. Expert RevNeurother. 2008;8(5):809-818.

20. Barbin J, Seetha V, Casillas JM, Paysant J, Perennou D. The effects of mirror therapy on pain and motor control of phantom limb in amputees: a systematic review. Ann Phys Rehabil Med. 2016;59(4):270-275.

21. Guyatt GH, Oxman AD, Vist GE, et al; GRADE Working Group. GRADE: an emerging consensus on rating quality of evidence and strength of recommendations. BMJ. 2008;336(7650):924-926.

22. Thieme H, Morkisch N, Rietz C, Dohle C, Borgetto B. The efficacy of movement representation techniques for treatment of limb pain-a systematic review and meta-analysis. J Pain. 2016;17(2):167-180.
23. Malavera A, Silva FA, Fregni F, Carrillo S, Garcia RG. Repetitive transcranial magnetic stimulation for phantom limb pain in land mine victims: a double-blinded, randomized, sham-controlled trial. J Pain. 2016;17(8):911-918.

24. Robinson LR, Czerniecki JM, Ehde DM, et al. Trial of amitriptyline for relief of pain in amputees: results of a randomized controlled study. Arch Phys Med Rehabil. 2004;85(1):1-6.

25. Bone M, Critchley P, Buggy DJ. Gabapentin in postamputation phantom limb pain: a randomized, double-blind, placebo-controlled, cross-over study. Reg Anesth Pain Med. 2002;27(5):481-486.

26. Smith DG, Ehde DM, Hanley MA, et al. Efficacy of gabapentin in treating chronic phantom limb and residual limb pain. J Rehabil Res Dev. 2005;42(5):645-654.

27. Abbass K. Efficacy of gabapentin for treatment of adults with phantom limb pain. Ann Pharmacother. 2012;46(12):1707-1711.

28. Nikolajsen L, Hansen CL, Nielsen J, Keller J, Arendt-Nielsen L, Jensen TS. The effect of ketamine on phantom pain: a central neuropathic disorder maintained by peripheral input. Pain. 1996;67(1):69-77.

29. Nikolajsen L, Gottrup H, Kristensen AG, Jensen TS. Memantine (a $\mathrm{N}$-methyl-D-aspartate receptor antagonist) in the treatment of neuropathic pain after amputation or surgery: a randomized, double-blinded, cross-over study. Anesth Analg. 2000;91(4):960-966.

30. Wiech K, Kiefer RT, Topfner S, et al. A placebo-controlled randomized crossover trial of the N-methyl-D-aspartic acid receptor antagonist, memantine, in patients with chronic phantom limb pain. Anesth Analg. 2004;98(2):408-413.

31. Maier C, Dertwinkel R, Mansourian N, et al. Efficacy of the NMDAreceptor antagonist memantine in patients with chronic phantom limb pain-results of a randomized double-blinded, placebo-controlled trial. Pain. 2003;103(3):277-283.

32. Wu CL, Tella P, Staats PS, et al. Analgesic effects of intravenous lidocaine and morphine on postamputation pain: a randomized double-blind, active placebo-controlled, crossover trial. Anesthesiology. 2002;96(4):841-848.

33. Wu CL, Agarwal S, Tella PK, et al. Morphine versus mexiletine for treatment of postamputation pain: a randomized, placebo-controlled, crossover trial. Anesthesiology. 2008;109(2):289-296.

34. Rogers AG. Use of amitriptyline (Elavil) for phantom limb pain in younger children. J Pain Symptom Manage. 1989;4(2):96.

35. Urban BJ, France RD, Steinberger EK, Scott DL, Maltbie AA. Longterm use of narcotic/antidepressant medication in the management of phantom limb pain. Pain. 1986;24(2):191-196.

36. Harwood DD, Hanumanthu S, Stoudemire A. Pathophysiology and management of phantom limb pain. Gen Hosp Psychiatry. 1992;14(2):107-118.

37. Iacono RP, Sandyk R, Bamford CR, Awerbuch G, Malone JM. Post-amputation phantom pain and autonomous stump movements responsive to doxepin. Funct Neurol. 1987;2(3):343-348.

38. Rusy LM, Troshynski TJ, Weisman SJ. Gabapentin in phantom limb pain management in children and young adults: report of seven cases. J Pain Symptom Manage. 2001;21(1):78-82.

39. Spiegel DR, Lappinen E, Gottlieb M. A presumed case of phantom limb pain treated successfully with duloxetine and pregabalin. Gen Hosp Psychiatry. 2010;32(2):228.e5-e7.

40. Harden RN, Houle TT, Remble TA, Lin W, Wang K, Saltz S. Topiramate for phantom limb pain: a time-series analysis. Pain Med. 2005;6(5):375-378.

41. Patterson JF. Carbamazepine in the treatment of phantom limb pain. South Med J. 1988;81(9):1100-1102.

42. Elliott F, Little A, Milbrandt W. Carbamazepine for phantom-limb phenomena. N Engl J Med. 1976;295(12):678.

43. Bartusch SL, Sanders BJ, D’Alessio JG, Jernigan JR. Clonazepam for the treatment of lancinating phantom limb pain. Clin J Pain. 1996;12(1):59-62.

44. Wall GC, Heyneman CA. Calcitonin in phantom limb pain. Ann Pharmacother. 1999;33(4):499-501.

45. Kessel C, Worz R. Immediate response of phantom limb pain to calcitonin. Pain. 1987;30(1):79-87. 
46. Eichenberger U, Neff F, Sveticic G, et al. Chronic phantom limb pain: the effects of calcitonin, ketamine, and their combination on pain and sensory thresholds. Anesth Analg. 2008;106(4):1265-1273.

47. Knox DJ, McLeod BJ, Goucke CR. Acute phantom limb pain controlled by ketamine. Anaesth Intensive Care. 1995;23(5):620-622.

48. Stannard CF, Porter GE. Ketamine hydrochloride in the treatment of phantom limb pain. Pain. 1993;54(2):227-230.

49. Sakai T, Sumikawa K. Phantom limb pain exacerbated by intravenous ketamine. J Anesth. 2014;28(4):643.

50. Hackworth RJ, Tokarz KA, Fowler IM, Wallace SC, Stedje-Larsen ET. Profound pain reduction after induction of memantine treatment in two patients with severe phantom limb pain. Anesth Analg. 2008;107(4):1377-1379.

51. Ben Abraham R, Marouani N, KollenderY, Meller I, Weinbroum AA. Dextromethorphan for phantom pain attenuation in cancer amputees: a double-blind crossover trial involving three patients. Clin J Pain. 2002;18(5):282-285.

52. Bergmans L, Snijdelaar DG, Katz J, Crul BJ. Methadone for phantom limb pain. Clin J Pain. 2002;18(3):203-205.

53. Wu H, Sultana R, Taylor KB, Szabo A. A prospective randomized double-blinded pilot study to examine the effect of botulinum toxin type A injection versus Lidocaine/Depomedrol injection on residual and phantom limb pain: initial report. Clin J Pain. 2012;28(2):108-112.

54. Davis RW. Successful treatment for phantom pain. Orthopedics. 1993;16(6):691-695.

55. Ilfeld BM, Moeller-Bertram T, Hanling SR, et al. Treating intractable phantom limb pain with ambulatory continuous peripheral nerve blocks: a pilot study. Pain Med. 2013;14(6):935-942.

56. Casale R, Ceccherelli F, Labeeb AA, Biella GE. Phantom limb pain relief by contralateral myofascial injection with local anaesthetic in a placebo-controlled study: preliminary results. $J$ Rehabil Med. 2009;41(6):418-422.

57. Lierz P, Schroegendorfer K, Choi S, Felleiter P, Kress HG. Continuous blockade of both brachial plexus with ropivacaine in phantom pain: a case report. Pain. 1998;78(2):135-137.

58. Huse E, Larbig W, Flor H, Birbaumer N. The effect of opioids on phantom limb pain and cortical reorganization. Pain. 2001;90(1-2):47-55.

59. Mishra S, Bhatnagar S, Singhal AK. High-dose morphine for intractable phantom limb pain. Clin J Pain. 2007;23(1):99-101.

60. Jacobson L, Chabal C, Brody MC. Relief of persistent postamputation stump and phantom limb pain with intrathecal fentanyl. Pain. 1989;37(3):317-322.

61. Oille WA. Beta adrenergic blockade and the phantom limb. Ann Intern Med. 1970;73(6):1044-1045.

62. Marsland AR, Weekes JW, Atkinson RL, Leong MG. Phantom limb pain: a case for beta blockers? Pain. 1982;12(3):295-297.

63. Ahmad S. Phantom limb pain and propranolol. $\mathrm{Br}$ Med J. 1979; 1(6160):415.

64. Power-Smith P, Turkington D. Fluoxetine in phantom limb pain. $B r J$ Psychiatry. 1993;163:105-106.

65. Sato K, Higuchi H, Hishikawa Y. Management of phantom limb pain and sensation with milnacipran. J Neuropsychiatry ClinNeurosci. 2008;20(3):368.

66. Stannard CF. Phantom limb pain. Br J Hosp Med. 1993;50(10):583-584.

67. Wesolowski JA, Lema MJ. Phantom limb pain. Reg Anesth. 1993;18(2):121-127.

68. Williams AM, Deaton SB. Phantom limb pain: elusive, yet real. Rehabil Nurs. 1997;22(2):73-77.

69. Weinstein SM. Phantom limb pain and related disorders. Neuro Clin. 1998;16(4):919-936.

70. Rath SA, Seitz K, Soliman N, Kahamba JF, Antoniadis G, Richter HP. DREZ coagulations for deafferentation pain related to spinal and peripheral nerve lesions: indication and results of 79 consecutive procedures. Stereotact Funct Neurosurg. 1997;68(1-4 Pt 1): $161-167$.

71. Ramazanov R, Dreval ON, Akatov OV, Zaretsky AA. Ultrasound microneurosurgery. Neurol Res. 1999;21(1):73-76.
72. Saris SC, Iacono RP, Nashold BS Jr. Successful treatment of phantom pain with dorsal root entry zone coagulation. Appl Neurophysiol. 1988;51(2-5):188-197.

73. Zheng Z, Hu Y, Tao W, Zhang X, Li Y. Dorsal root entry zone lesions for phantom limb pain with brachial plexus avulsion: a study of pain and phantom limb sensation. Stereotact Funct Neurosurg. 2009;87(4):249-255.

74. Tomycz ND, Moossy JJ. Follow-up 26 years after dorsal root entry zone thermocoagulation for brachial plexus avulsion and phantom limb pain. J Neurosurg. 2011;114(1):196-199.

75. Xing G. Acupuncture treatment of phantom limb pain-a report of 9 cases. J Tradit Chin Med. 1998;18(3):199-201.

76. Monga TN, Jaksic T. Acupuncture in phantom limb pain. Arch Phys Med Rehabil. 1981;62(5):229-231.

77. Lu TV. Acupuncture treatment for phantom limb pain. Altern Ther Health Med. 1998;4(5):124.

78. Bradbrook D. Acupuncture treatment of phantom limb pain and phantom limb sensation in amputees. Acupunct Med. 2004;22(2):93-97.

79. Xue CC. Acupuncture induced phantom limb and meridian phenomenon in acquired and congenital amputees. A suggestion of the use of acupuncture as a method for investigation of phantom limb. Chin Med J. 1986;99(3):247-252.

80. Sherman RA, Gall N, Gormly J. Treatment of phantom limb pain with muscular relaxation training to disrupt the pain-anxiety-tension cycle. Pain. 1979;6(1):47-55.

81. Harden RN, Houle TT, Green S, et al. Biofeedback in the treatment of phantom limb pain: a time-series analysis. Appl Psychophysiol Biofeedback. 2005;30(1):83-93.

82. Belleggia G, Birbaumer N. Treatment of phantom limb pain with combined EMG and thermal biofeedback: a case report. Appl Psychophysiol Biofeedback. 2001;26(2):141-146.

83. Dougherty J. Relief of phantom limb pain after EMG biofeedbackassisted relaxation: a case report. Behav Res Ther. 1980;18(4): 355-357

84. Flor H, Denke C, Schaefer M, Grusser S. Effect of sensory discrimination training on cortical reorganisation and phantom limb pain. Lancet. 2001;357(9270):1763-1764.

85. Conine TA, Hershler C, Alexander SA, Crisp R. The efficacy of Farabloc in the treatment of phantom limb pain. Canadian J Rehabil. Spring 1993;6(3):155-161.

86. Rickard JA. Effects of hypnosis in the treatment of residual stump pain and phantom limb pain [dissertation]. Abstracts International: Section B: The Sciences and Engineering; 2005.

87. Bamford C. A multifaceted approach to the treatment of phantom limb pain using hypnosis. Contemporary Hypnosis. 2006;23(3):115-126.

88. Siegel EF. Control of phantom limb pain by hypnosis. Am J Clin Hypn. 1979;21(4):285-286.

89. Rosen G, Willoch F, Bartenstein P, Berner N, Rosjo S. Neurophysiological processes underlying the phantom limb pain experience and the use of hypnosis in its clinical management: an intensive examination of two patients. Int J Clin Exp Hypn. 2001;49(1):38-55.

90. Oakley DA, Whitman LG, Halligan PW. Hypnotic imagery as a treatment for phantom limb pain: two case reports and a review. Clin Rehabil. 2002;16(4):368-377.

91. Chan R. Hypnosis and phantom limb pain. Australian Journal of Clinical \& Experimental Hypnosis. Australian Society of Hypnosis; 2006

92. Brown C, Lido C. Reflexology treatment for patients with lower limb amputations and phantom limb pain-an exploratory pilot study. Complement Ther Clin Pract. 2008;14(2):124-131.

93. Johnson MI, Mulvey MR, Bagnall AM. Transcutaneous electrical nerve stimulation (TENS) for phantom pain and stump pain following amputation in adults. Cochrane Database Syst Rev. 2015;8:CD007264.

94. Lundeberg T. Relief of pain from a phantom limb by peripheral stimulation. J Neurol. 1985;232(2):79-82.

95. Finsen V, Persen L, Lovlien M, et al. Transcutaneous electrical nerve stimulation after major amputation. J Bone Joint Surg Br. 1988;70(1):109-112. 
96. Carabelli RA, Kellerman WC. Phantom limb pain: relief by application of TENS to contralateral extremity. Arch Phys Med Rehabil. 1985;66(7):466-467.

97. Salim M. Transcutaneous electrical nerve stimulation in phantom limb pain. Altern Ther Clin Pract. 1997;4(4):135-137.

98. Giuffrida O, Simpson L, Halligan PW. Contralateral stimulation, using tens, of phantom limb pain: two confirmatory cases. Pain Med. 2010;11(1):133-141.

99. Katz J, Melzack R. Auricular transcutaneous electrical nerve stimulation (TENS) reduces phantom limb pain. J Pain Symptom Manage. 1991;6(2):73-83.

100. Winnem MF, Amundsen T. Treatment of phantom limb pain with TENS. Pain. 1982;12(3):299-300.

101. Mulvey MR, Radford HE, Fawkner HJ, Hirst L, Neumann V, Johnson MI. Transcutaneous electrical nerve stimulation for phantom pain and stump pain in adult amputees. Pain Pract. 2013;13(4):289-296.

102. Aiyer R, Barkin RL, Bhatia A, Gungor S. A systematic review on the treatment of phantom limb pain with spinal cord stimulation. Pain Manage. 2017;7(1):59-69.

103. Krainick JU, Thoden U, Riechert T. Pain reduction in amputees by long-term spinal cord stimulation. Long-term follow-up study over 5 years. J Neurosurg. 1980;52(3):346-350.

104. Cassina I, Pinelli NM, Bentivegna E, et al. S.C.S. effectiveness in patients affected by peripheral chronic arterial disease: our 5 years experience. Int Angiol. 1993;12(4):378-382.

105. van Dongen VCP, Liem AL. Phantom limb and stump pain and its treatment with spinal cord stimulation. J Rehabil Sci. 1995;8(4): $110-114$.

106. Kumar K, Toth C, Nath RK, Laing P. Epidural spinal cord stimulation for treatment of chronic pain-some predictors of success. A 15-year experience. Surg Neurol. 1998;50(2):110-120; discussion 120-111.

107. Katayama Y, Yamamoto T, Kobayashi K, Kasai M, Oshima H, Fukaya C. Motor cortex stimulation for phantom limb pain: comprehensive therapy with spinal cord and thalamic stimulation. Stereotact Funct Neurosurg. 2001;77(1-4):159-162.

108. Carroll D, Joint C, Maartens N, Shlugman D, Stein J, Aziz TZ. Motor cortex stimulation for chronic neuropathic pain: a preliminary study of 10 cases. Pain. 2000;84(2-3):431-437.

109. Saitoh Y, Hirano S, Kato A, et al. Motor cortex stimulation for deafferentation pain. Neurosurg Focus. 2001;11(3):1-5.

110. Roux FE, Ibarrola D, Lazorthes Y, Berry I. Chronic motor cortex stimulation for phantom limb pain: a functional magnetic resonance imaging study: technical case report. Neurosurgery. 2001;48(3):681-687; discussion 687-688.

111. Sol JC, Casaux J, Roux FE, et al. Chronic motor cortex stimulation for phantom limb pain: correlations between pain relief and functional imaging studies. Stereotact Funct Neurosurg. 2001;77(1-4):172-176.

112. Pereira EAC, Moore T, Moir L, Aziz TZ. Long-term motor cortex stimulation for phantom limb pain. Br J Neurosurg. 2015;29(2): $272-274$.

113. Kumar K, Wyant GM, Nath R. Deep brain stimulation for control of intractable pain in humans, present and future: a ten-year follow-up. Neurosurgery. 1990;26(5):774-781; discussion 781-772.

114. Bittar RG, Otero S, Carter H, Aziz TZ. Deep brain stimulation for phantom limb pain. J Clin Neurosc. 2005;12(4):399-404.
115. Rasmussen KG, Rummans TA. Electroconvulsive therapy for phantom limb pain. Pain. 2000;85(1-2):297-299.

116. Fukui S, Shigemori S, Komoda Y, Yamada N, Nosaka S. Phantom pain with beneficial response to electroconvulsive therapy (ECT) and regional cerebral blood flow (rCBF) studied with xenon-CT. Pain clinic. 2002;13(4):355-359.

117. Ahmed MA, Mohamed SA, Sayed D. Long-term antalgic effects of repetitive transcranial magnetic stimulation of motor cortex and serum beta-endorphin in patients with phantom pain. Neurol Res. 2011;33(9):953-958.

118. Bolognini N, Spandri V, Ferraro F, et al. Immediate and sustained effects of 5-day transcranial direct current stimulation of the motor cortex in phantom limb pain. J Pain. 2015;16(7):657-665.

119. Grammer GG, Williams-Joseph S, Cesar A, Adkinson DK, Spevak C. Significant reduction in phantom limb pain after low-frequency repetitive transcranial magnetic stimulation to the primary sensory cortex. Mil Med. 2015;180(1):e126-e128.

120. Biley FC. Rogerian science, phantoms, and therapeutic touch: exploring potentials. Nurs Sci Q. Winter 1996;9(4):165-169.

121. Leskowitz ED. Phantom limb pain treated with therapeutic touch: a case report. Arch Phys Med Rehabil. 2000;81(4):522-524.

122. Ferraro F, Jacopetti M, Spallone V, et al; Italian Consensus Conference on Pain in Neurorehabilitation (ICCPN). Diagnosis and treatment of pain in plexopathy, radiculopathy, peripheral neuropathy and phantom limb pain. Evidence and recommendations from the Italian Consensus Conference on Pain on Neurorehabilitation. Eur J Phys Rehabil Med. 2016;52(6):855-866.

123. Cepeda MS, Africano JM, Polo R, Alcala R, Carr DB. Agreement between percentage pain reductions calculated from numeric rating scores of pain intensity and those reported by patients with acute or cancer pain. Pain. 2003;106(3):439-442.

124. Forouzanfar T, Weber WEJ, Kemler M, van Kleef M. What is a meaningful pain reduction in patients with complex regional pain syndrome type 1? Clin J Pain. 2003;19(5):281-285.

125. Casale R, Damiani C, Rosati V. Mirror therapy in the rehabilitation of lower-limb amputation: are there any contraindications? Am J Phys Med Rehabil. 2009;88(10):837-842.

126. Hanling SR, Wallace SC, Hollenbeck KJ, Belnap BD, Tulis MR. Preamputation mirror therapy may prevent development of phantom limb pain: a case series. Anesth Analg. 2010;110(2):611-614.

127. Weeks SR, Anderson-Barnes VC, Tsao JW. Phantom limb pain: theories and therapies. Neurologist. 2010;16(5):277-286.

128. Rothgangel AS, Braun SM, Beurskens AJ, Seitz RJ, Wade DT. The clinical aspects of mirror therapy in rehabilitation: a systematic review of the literature. Int J Rehabil Res. 2011;34(1):1-13.

129. Brodie EE, Whyte A, Niven CA. Analgesia through the looking-glass? A randomized controlled trial investigating the effect of viewing a 'virtual' limb upon phantom limb pain, sensation and movement. Eur J Pain. 2007;11(4):428-436.

130. Brunelli S, Morone G, Iosa M, et al. Efficacy of progressive muscle relaxation, mental imagery, and phantom exercise training on phantom limb: a randomized controlled trial. Arch Phys Med Rehabil. 2015;96(2):181-187.

131. Yildirim M, Kanan N. The effect of mirror therapy on the management of phantom limb pain. Agri. 2016;28(3):127-134.
Journal of Pain Research

\section{Publish your work in this journal}

The Journal of Pain Research is an international, peer reviewed, open access, online journal that welcomes laboratory and clinical findings in the fields of pain research and the prevention and management of pain. Original research, reviews, symposium reports, hypothesis formation and commentaries are all considered for publication.
The manuscript management system is completely online and includes a very quick and fair peer-review system, which is all easy to use. Visit http://www.dovepress.com/testimonials.php to read real quotes from published authors. 